\title{
Gravity Survey of Dixie Valley, West-Central Nevada
}

By Donald H. Schaefer

\section{U.S. GEOLOGICAL SURVEY}

Open-File Report 82-111

Prepared in cooperation with the

U.S. BUREAU OF LAND MANAGEMENT

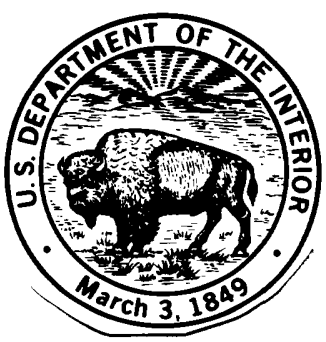

Carson City, Nevada 


\author{
UNITED STATES DEPARTMENT OF THE INTERIOR \\ JAMES G. WATT, Secretary \\ GEOLOGICAL SURVEY \\ Dallas L. Peck, Director
}

For additional information write to:

U.S. Geological Survey Room 229, Federal Building 705 North Plaza Street Carson City, NV 89701
Copies of this report may be purchased from:

Open-File Services Section

U.S. Geological Survey

Box 25425, Federal Center

Denver, CO 80225

Cal1 (303) 234-5888 for

ordering information 


\section{CONTENTS}

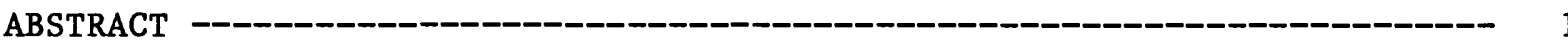

INTRODUCTION -

Physical setting -_-_-_-_-_-_-_ 2

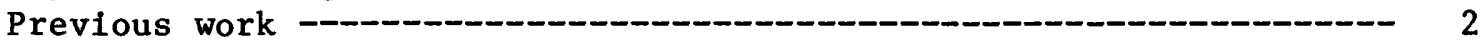

Purpose and scope -_-_-_-_- 2

Geology -

Geothermal exploration -_- 5

Acknowledgments --_-_- 5

GRAVITY-DATA COLLECTION AND REDUCTION -

Purpose and methods -- 5

Field techniques - 6

Horizontal control

Vertical control - 8

Observed gravity: data correction and reduction --_---_----- 8

Bouguer anomalies -_- 9

GRAVITY INTERPRETATIONS -

Regional and residual gravity - 9

Depth to bedrock and geologic structure -

Limitations of the survey

RELATION BETWEEN BEDROCK CONFIGURATION,

GEOTHERMAL DEVELOPMENT, AND SEISMICITY - 15

REFERENCES CITED - 


\section{ILLUSTRATIONS}

[Plates are in pocket at back of report]

Plate 1. Map showing Bouguer anomalies

2. Map showing depth to bedrock

Figures 1-4. Maps showing:

1. Geology, hot springs, and geothermal wells - 3

2. Gravity stations and profile lines 7

3. Residual-gravity values __ 10

4. Location of seismic-refraction profiles - 12

TABLES

Table 1. Comparison of depths to bedrock calculated from seismic and gravity surveys 13

2. Maximum depths with different densities 14 


\section{CONVERSION FACTORS}

Except for geophysical and related units of measure, only the inch-pound system is used in this report. Conversion factors from inch-pound to metric units are listed below.
Multiply
By
To obtain
Feet
0.3048
Meters
Miles
1.609
Kilometers

Geophysical and related units of measure used in this report are as follows:

For gravity, Gals and milliGals.

For density, grams per cubic centimeter.

\section{ALTITUDE DATUM}

The term "National Geodetic Vertical Datum of 1929" (abbreviation, NGVD of 1929) replaces the formerly used term "mean sea level" to describe the datum for altitude measurements. The NGVD of 1929 is derived from a general adjustment of the first-order leveling networks of both the United States and Canada. For convenience in this report, the datum also is referred to as "sea leve1." 


\section{GRAVITY SURVEY OF DIXIE VALLEY, \\ WEST-CENTRAL NEVADA}

By Donald H. Schaefer

\section{ABSTRACT}

Dixie Valley, a northeast-trending structural trough typical of valleys in the Basin and Range Province, is filled with a maximum of about 10,000 feet of alluvial and lacustrine deposits, as estimated from residual-gravity measurements obtained in this study.

On the basis of gravity measurements at 300 stations on nine east-west profiles, the gravity residuals reach a maximum of $30 \mathrm{milliGals}$ near the south-central part of the valley. Results from a three-dimensional inversion model indicate that the central depression of the valley is offset to the west of the geographic axis. This offset is probably due to major faulting along the west side of the valley adjacent to the Stillwater Range.

Comparison of depths to bedrock obtained during this study and depths obtained from a previous seismic-refraction study indicates a reasonably good correlation. A heterogeneous distribution of densities within the valley-fill deposits would account for differing depths determined by the two methods. 


\section{INTRODUCTION}

\section{Physical Setting}

Dixie Valley, approximately 35 miles northeast of Fallon, Nev. (figure 1), is a northeast-trending structural trough. The valley is about 50 miles in length and attains a maximum width of 14 miles. It is bordered on the west and northwest by the Stillwater Range, on the east and southeast by the Clan Alpine Mountains, on the south by Fairview Valley, and on the north by the Tobin Range. The bordering mountains reach a maximum altitude of about 8,900 feet above sea level and have a maximum relief of more than 4,000 feet above the valley floor.

The valley floor slopes toward the Humboldt Salt Marsh in the west-central part of the basin. The salt marsh is a playa underlain by thick accumulations of salt and mud. Dixie Hot Springs and numerous other springs in the adjacent mountains and alluvial fans, along with occasional runoff from the mountains, keep the playa covered with water throughout most of the year.

Agriculture is the only industry in the valley. Alfalfa is cultivated for seed and feed, and cattle are grazed throughout the valley.

\section{Previous Work}

The ground-water system of Dixie Valley was studied in a reconnaissance by Cohen and Everett (1963). Wells in the valley were inventoried, and some aspects of ground-water quality were discussed.

The geology has been studied in detail by many investigators interested in the seismic, tectonic, and geothermal activity in the valley. The overall geology was mapped by Willden and Speed (1974) and Johnson (1977).

Another intensive study was that of Thompson and others (1967), which included geologic as well and geophysical aspects. Effects of earthquakes on wells and springs in Dixie Valley were described by Zones (1957). In recent years, due to increased interest in the geothermal resources of the valley, energy companies have undertaken geophysical and geologic studies in several parts of the valley. Many of these data have not yet been released to the public.

\section{Purpose and Scope}

The purpose of the study, prepared in cooperation with the U.S. Bureau of Land Management, was to provide the Bureau with the necessary information to assess the geothermal resources of Dixie Valley and determine the potential for interaction between the thermal and non-thermal ground-water systems. 


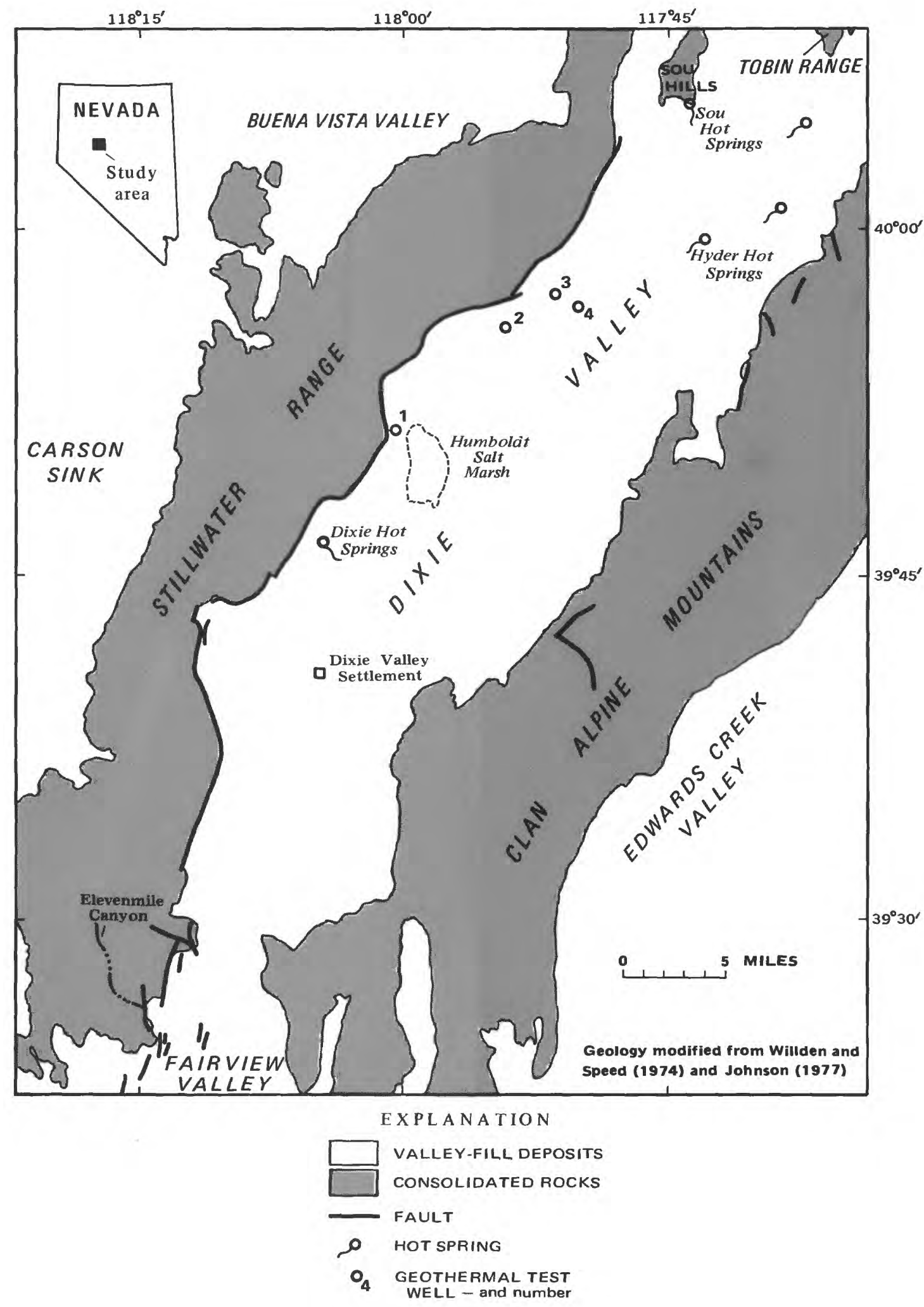

FIGURE 1. - Geology, hot springs, and geothermal wells. 
The items of particular interest to the Bureau of Land Management were:

(1) The depth to and subsurface configuration of the bedrock surface underlying Dixie Valley. These data are critical to the total understanding of the ground-water system in the valley, and may also define major faulting in the area that could affect ground-water flow patterns. Depth to bedrock is the only one discussed in detail in this report. The gravity survey consisted of eight profiles across the valley from bedrock outcrop to bedrock outcrop. These profiles were used to determine the thickness of valley-fill deposits and map the bedrock surface.

(2) The collection of existing ground-water data and its storage in the U.S. Geological Survey's WATSTORE data base. This makes the data more readily available for future ground-water studies. Storage of existing ground-water data was accomplished by abstracting information from the report by Cohen and Everett (1963). No additional data were collected for this study.

(3) The monitoring of seismic activity in the valley during the flow test of a geothermal test well. As Dixie Valley is historically a seismically active area (S1emmons, 1957; Westpha1 and Lange, 1967), the Bureau of Land Management is interested in possible seismic hazards, should large-scale geothermal development occur in the future. The seismic monitoring was done by the U.S. Geological Survey's Office of Earthquake Studies, Menlo Park, Calif.

\section{$\underline{\text { Geology }}$}

The two bordering mountain ranges in Dixie Valley (figure 1), the Stil1water Range on the west and the Clan Alpine Mountains on the east, are complex fault blocks composed of consolidated rocks ranging in age from Mesozoic to Cenozoic (Meister, 1967, page 5). These consolidated rocks border and underlie the valley-fill deposits.

The complex geology of the area was mapped by Willden and Speed (1974) and Johnson (1977). For this report, the geology has been generalized and the rock types grouped in two units: Consolidated rocks and valley-fill deposits (figure 1). The consolidated rocks consist of Triassic limestone and slate; Triassic volcanic, intrusive, and metavolcanic rocks; Mesozoic granitic rocks; and Cenozoic volcanic and sedimentary rocks. The valley-fill deposits consist of alluvial material derived from the surrounding mountains and lacustrine deposits of late Miocene to Holocene age.

The structural history of the valley, which also is very complex, is not discussed in detail in this report. For a detailed discussion of the geologic structure of Dixie Valley, the reader is referred to the report by Willden and Speed (1974). Within the last 100 years, tectonic movement within the valley has caused several earthquakes, the largest of which occurred in 1954 and had a magnitude of about 7 on the Richter scale (S1emmons and others, 1965, page 558). This earthquake in turn caused several local changes in groundwater conditions, such as increased flow rates of wells and springs and increases in the temperature of that flow. Water levels in nonflowing wells also changed after the earthquake (Zones, 1957). 
Numerous hot springs and the data obtained from deep test wells indicate the existence of a geothermal resource in Dixie Valley (figure 1). Recently, various energy companies have made geologic and geophysical studies in the area to determine the extent of this resource. Numerous shallow (500 feet or less) temperature holes have been drilled in the valley by those companies to delineate subsurface lithology and heat-flow patterns. This shallow test drilling has been accompanied by the drilling of several deep geothermal test holes, as shown on figure 1. As of 1980, the deepest hole drilled in Dixie Valley was more than 12,000 feet deep (we11 4, figure 1).

Plans to develop the geothermal resources of the valley include the installation and operation of a 10-megawatt electrical generation plant (Norman W. Melvin, U.S. Bureau of Land Management, oral commun., 1980).

\section{Acknowledgments}

The author thanks the staff of the Reno State Office and Carson City District Office, U.S. Bureau of Land Management, for their assistance in this study. The author also thanks the Chester B. Knittle family, Dixie Valley, for their help and hospitality during the study.

\section{GRAVITY-DATA COLLECTION AND REDUCTION}

\section{Purpose and Methods}

The purpose of the gravity survey in Dixie Valley was to estimate the thickness of valley-fill deposits. In general, thick accumulations of these deposits may provide for long-term withdrawal of geothermal fluids because of the great volume of water stored within them. An additional product of a gravity survey is the detection of possible large-scale faulting patterns in the area. Faults can act as barriers to retard the movement of ground water or as conduits for the flow of water, possibly of poor quality. In the past, gravity surveys have been found to be a rapid and reasonably accurate method for the determination of bedrock depths.

Gravimetry is a geophysical technique that measures the vertical acceleration of gravity at discrete points on the Earth's surface. In these studies, the gravitational variations are measured in milliGals $\left(10^{-3} \mathrm{Gal}\right)$, where $1.0 \mathrm{Gal}$ is equal to an acceleration of 1.0 centimeter per second, per second.

A more complete description of the theory used in gravimetric surveys can be found in most geophysics textbooks, such as that of Dobrin (1976, page 357403). Basically, the method involves measurements of very sma11 variations in the gravitational attraction on the Earth's surface that can be attributed to density variations in the material beneath the surface. For example, a 
structural basin filled with low-density alluvial and lacustrine deposits underlain by a relatively high-density crystalline bedrock shows a gravity profile across the basin that is smaller numerically than if bedrock were exposed at land surface throughout. The difference between what the gravity profile would be if there were no valley-fill material and what it would be in the presence of low-density deposits is referred to as a gravity anomaly. The thickness of the low-density material overlying the higher density material is proportional to the magnitude of the anomaly, and can be determined by field surveys.

\section{Field Techniques}

Gravity measurements were obtained at 300 locations in Dixie Valley (figure 2) using a Worden ${ }^{1}$ Master-mode1 gravimeter with a dial constant of 0.0965 milliGal per scale division. The stations were positioned along nine generally east-west profiles originally planned at 5-mile intervals. Some of the planned profiles were relocated during the study due to rugged or impassable terrain. Profiles cover the area from the southern margin of the valley near Eleven Mile Canyon (line A) to the northern margin near the Sou Hills (line $\mathrm{K}$, figure 2). Stations along the nine profiles were spaced at 2,000 -foot intervals, from bedrock outcrop on one side of the valley to bedrock outcrop on the other side.

One profile (line $J$ ) was started at its west end, but was not completed because of poor access. Profile $F$ has a 2-mile gap because the Humboldt Salt Marsh (figure 2) had standing water and mud which made travel impossible.

In addition to the profiles, many gravity readings were obtained at road intersections and benchmarks throughout the valley (figure 2) to supplement the profile data.

\section{Horizontal Control}

Horizontal control for gravity stations on each profile was accomplished using the loran navigation system. Loran is a U.S. Coast Guard system used for coastal navigation.

A fixed master transmitter and a number of fixed secondary transmitters broadcast a series of precisely coded signals that are received by a vehiclemounted receiver. The arrival time of the signals is translated into a latitude and longitude position by a microprocessor within the receiver. The system has certain inherent inaccuracies, but corrections applied to the position fix allowed an accuracy of about 0.01 minute of latitude and longitude (approximately $60 \mathrm{feet}$ ) to be obtained. A more complete description of loran theory and operation is given by Laurila (1976, pages 419-435).

1 The use of a brand name is for identification purposes only and does not imply endorsement by the U.S. Geological Survey. 


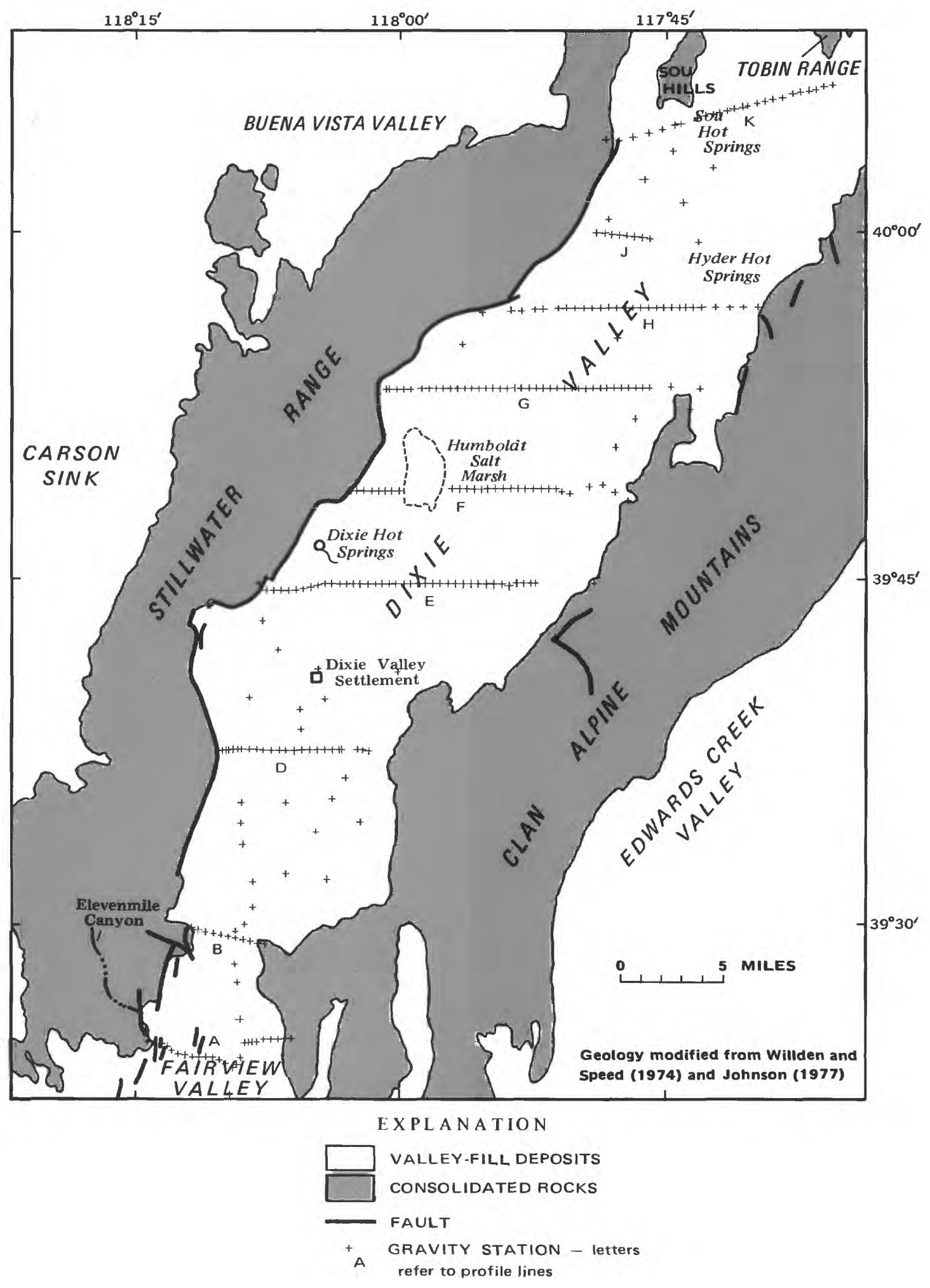

FIGURE 2. - Gravity stations and profile lines. 
The loran system was also used to maintain a heading along the correct line of latitude for any given profile. Profiles $A, B$, and $K$ were located on existing roads. Individual station spacings at 2,000-foot intervals were determined using an electronic odometer.

Some stations located on bedrock outcrops at the ends of profiles were surveyed with an electronic transit. The remaining supplementary stations were at benchmarks and road intersections; latitudes and longitudes were determined with loran and checked with a latitude-longitude determination from a largescale topographic map.

\section{Vertical Control}

The altitude of an individual gravity station is one of the most critical parameters measured during a gravimetric survey. Errors of as little as 5 feet of altitude yield an error in calculated gravity of about 0.3 milliGal. The ideal method to determine station altitude is to survey each site. However, due to time limitations and the large areal extent of the study area, altitudes were obtained using a surveying altimeter. The altimeter used was readable to \pm 2 feet. With frequent reference to sites of known altitude and corrections for barometric pressure change during the day, the altimeter was considered accurate to \pm 5 feet or less.

Stations at benchmarks and road intersections having altitudes shown on a map are probably accurate to \pm 1 foot. For stations at the ends of profiles, altitudes established by transit survey are accurate to \pm 0.1 foot.

\section{Observed Gravity: Data Correction and Reduction}

A11 gravity measurements were referenced to two project base stations in the study area. At the beginning and end of each day, one of these base stations was reoccupied to determine instrument drift. Repeated reoccupation of the base stations also served as a check on the instrument drift of the loran receiver. The project base stations in turn were referenced to the primary base station in Fallon, Nev., for which the adopted value of observed gravity is $979,744.67$ milliGals, and from this value the observed gravity values for all stations were computed.

Gravity data were corrected for tidal variations, latitude, and altitude. Theoretical gravity, free-air anomalies, and Bouguer-gravity values at a density of $2.67 \mathrm{~g} / \mathrm{cm}^{3}$ (grams per cubic centimeter) were computed for all stations. A computer program, using the routine developed by Plouff (1977), was used to make terrain corrections to the Bouguer-gravity values at each station radially outward from 1.4 miles to about 104 miles. Terrain corrections within the $1.4-$ mile radius were done manually using the technique developed by Hayford and Bowie (1912).

The purpose of the corrections is to reduce all gravity measurements to a common altitude datum and make compensations for stations that overlie excessive or insufficient mass. The results of these corrections are the Bouguergravity values, which reflect spatial variations in mass across the study area. 


\section{Bouguer Anomalies}

Bouguer-gravity values, when contoured, reveal anomalies associated with excess or insufficient mass at depth. Plate 1 shows lines of equal Bouguer gravity in Dixie Valley. Bouguer values range from -180 to about -135 milligals. The smaller negative values are associated with the surrounding mountain ranges. The larger negative values indicated thick valley-fill deposits overlying the bedrock. For example, the thickest section of valley-fill deposits as indicated by the equal-gravity lines is toward the northwest side of the valley, west of the geographic center. This is shown by a large negative Bouguer value and closed gravity lines (plate 1).

\section{GRAVITY INTERPRETATIONS}

\section{$\underline{\text { Regiona1 and Residual Gravity }}$}

The eight profiles across the valley were used to determine regional gradients and to construct a map of residual gravity for Dixie Valley. Regional gravity trends approximate the gravity configuration that would be observed if the less-dense alluvial and lacustrine material in the basin were replaced by typical bedrock. Regional-gravity values reflect the more deep-seated structural differences, and are computed from data for the bedrock end-points of each profile. These endpoints describe a linear change that, for the purposes of this study, approximates the regional gravity field. Although the regional change is probably more complex than a simple linear trend surface, this approximation is quite suitable for the analysis of depth to bedrock in the valley.

The residual component of the Bouguer-gravity values is computed for each station along a profile by subtracting the regional gradient at that station. A residual-gravity map based on values computed from the profiles is shown in figure 3. The map is superimposed on a generalized geologic map to show relationships between gravity and geology. Some of the residual-gravity lines have been removed for clarity.

The residual-gravity map most accurately reflects the subsurface bedrock structure as derived from the gravity survey. On such a map, the 0-milliGal line, if it were shown, would indicate where the Bouguer gravity equals the regional gravity. This situation is common where bedrock is at or near land surface, and the $0-m i l 1 i G a 1$ line is therefore assumed to generally follow the bedrock-valley-fill contact.

The largest residual value on the map, about $30 \mathrm{milliGals,} \mathrm{occurs} \mathrm{at}$ three locations (figure 3). The contours are closely spaced along the known fault adjacent to the Stillwater Range, and the geographic axis of the valley is shifted to the west. 


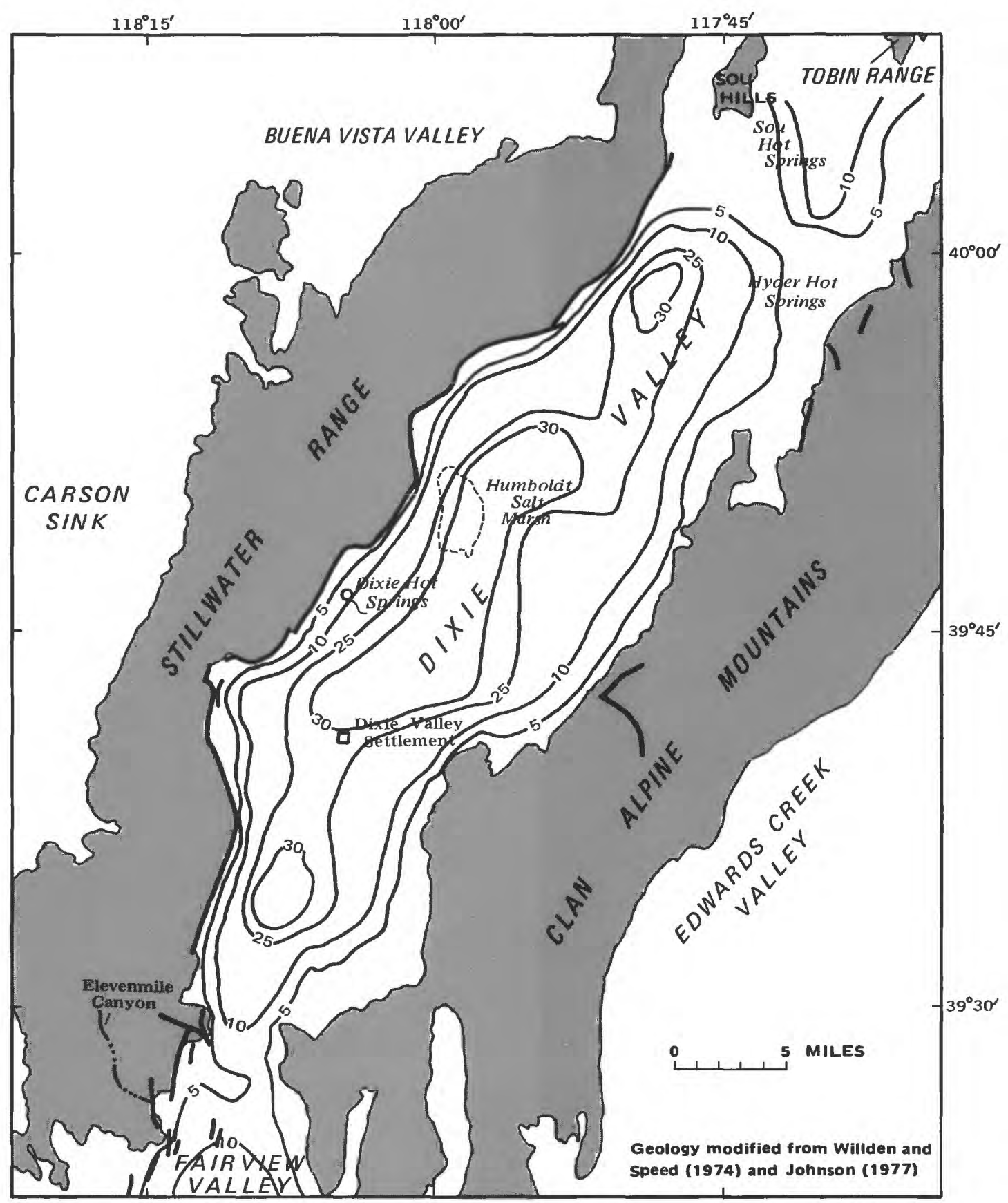

EXPLANATION

$\square$ VALLEY-FILL DEPOSITS
CONSOLIDATED ROCKS

- FAULT

-5- LINE OF EQUAL RESIDUAL.

GRAVITY - in milligals.

interval is variable

FIGURE 3. - Residual-gravity values. 


\section{Depth to Bedrock and Geologic Structure}

Depths to bedrock beneath the valley fill in Dixie Valley were calculated using the residual-gravity values from the eight profiles as input to a three-dimensional gravity-inversion model developed by Cordell (1970). The model is based on a technique described in Cordell and Henderson (1968), who also discussed limitations of the model. Data put into the model include the density contrast between bedrock and valley-fill deposits and the residualgravity values at points in a regularly spaced grid. The model then computes possible geologic solutions to the residual-gravity values until a reasonable fit of observed and calculated residual values is obtained.

The density contrast is by far the most sensitive parameter in the model. Unfortunately, this parameter has the highest degree of uncertainty. A density contrast of $0.5 \mathrm{~g} / \mathrm{cm}^{3}$ was estimated for the Dixie Valley model. This corresponds to a density of $2.17 \mathrm{~g} / \mathrm{cm}^{3}$ for the valley-fill deposits versus $2.67 \mathrm{~g} / \mathrm{cm}^{3}$ for the underlying bedrock. These values are within a reasonable range of densities for unconsolidated to semiconsolidated alluvial-type and granitic material, respectively (Telford and others, 1976, pages 24-28). The effects of an inaccurate density-contrast determination on depth-to-bedrock determinations are discussed in the next section.

Plate 2 is the depth-to-bedrock map for Dixie Valley; in many ways, it resembles the residual-gravity map. Maximum depths obtained from the inversion model are on the order of 10,000 feet, in a depression about 7 miles southwest of the Dixie Valley settlement. Two smaller depressions about 9,000 and 8,000 feet deep are about 2 miles north and 4 miles northeast of the settlement, respectively. Another large depression about 9,000 feet deep is about 15 miles northeast of the Humboldt Salt Marsh.

Faulting and resultant displacement of the bedrock surface under the valley-fill deposits can be indicated by closely spaced or highly distorted lines of equal gravity. Intensive faulting is indicated along the front of the Stillwater Range (plate 1). Very little evidence of faulting is indicated on the east side of the valley, where the general trend of gravity lines blends readily with the topographic contour of the Clan Alpine Mountains.

One prominent feature on the Bouguer map is the manner in which the lines of equal gravity are bent in the vicinity of Dixie Hot Springs (plate 1). While not evident from present geologic mapping, this may indicate an intersection of two or more faults in this vicinity. Transverse faulting, suggested in the vicinity of Dixie Valley settlement by east-trending depth lines, has resulted in two major depressions, north and south of the settlement, that are separated by a bedrock high at a depth of about 5,000 feet.

Seismic-refraction studies in Dixie Valley by Meister (1967) included estimates of depth to the water table and to the bedrock surface. Their refraction-profile lines are shown in figure 4. 


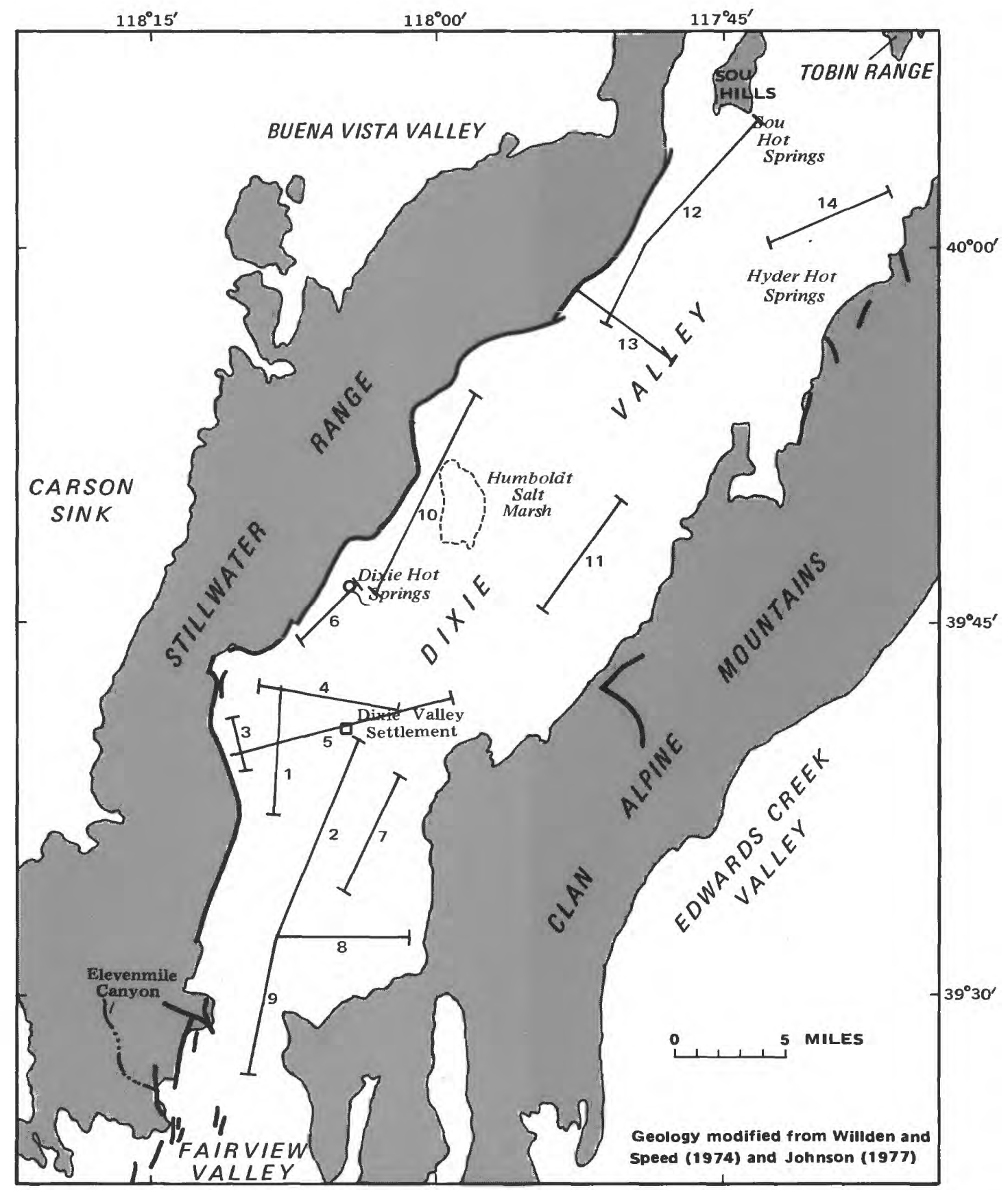

EXPLANATION

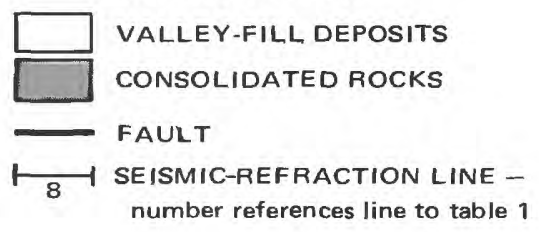

FIGURE 4. - Location of seismic-refraction profiles (from Meister, 1967, figure 2). 
Depth-to-bedrock determinations by seismic refraction were used as a check against depths computed from residual-gravity data. The comparisons are listed in table 1 . In general, the two sets of depth determinations are in good agreement. Of the depths computed in the seismic-refraction study, about 67 percent are within 1,000 feet of the depths computed using the three-dimensional inversion model and gravity data.

Most of the differences between seismic- and gravity-calculated depths to bedrock can probably be attributed to invalid density contrasts assumed in the inversion model. For this study, sufficient data are not available to determine actual variations in density along each profile; as a result, only one density-contrast was used for the entire study area. Use of different values for density contrast would result in different solutions. A discussion in the next section demonstrates the sensitivity of the depth estimates to small changes in density contrast.

TABLE 1.--Comparison of depths to bedrock calculated from seismic and gravity surveys

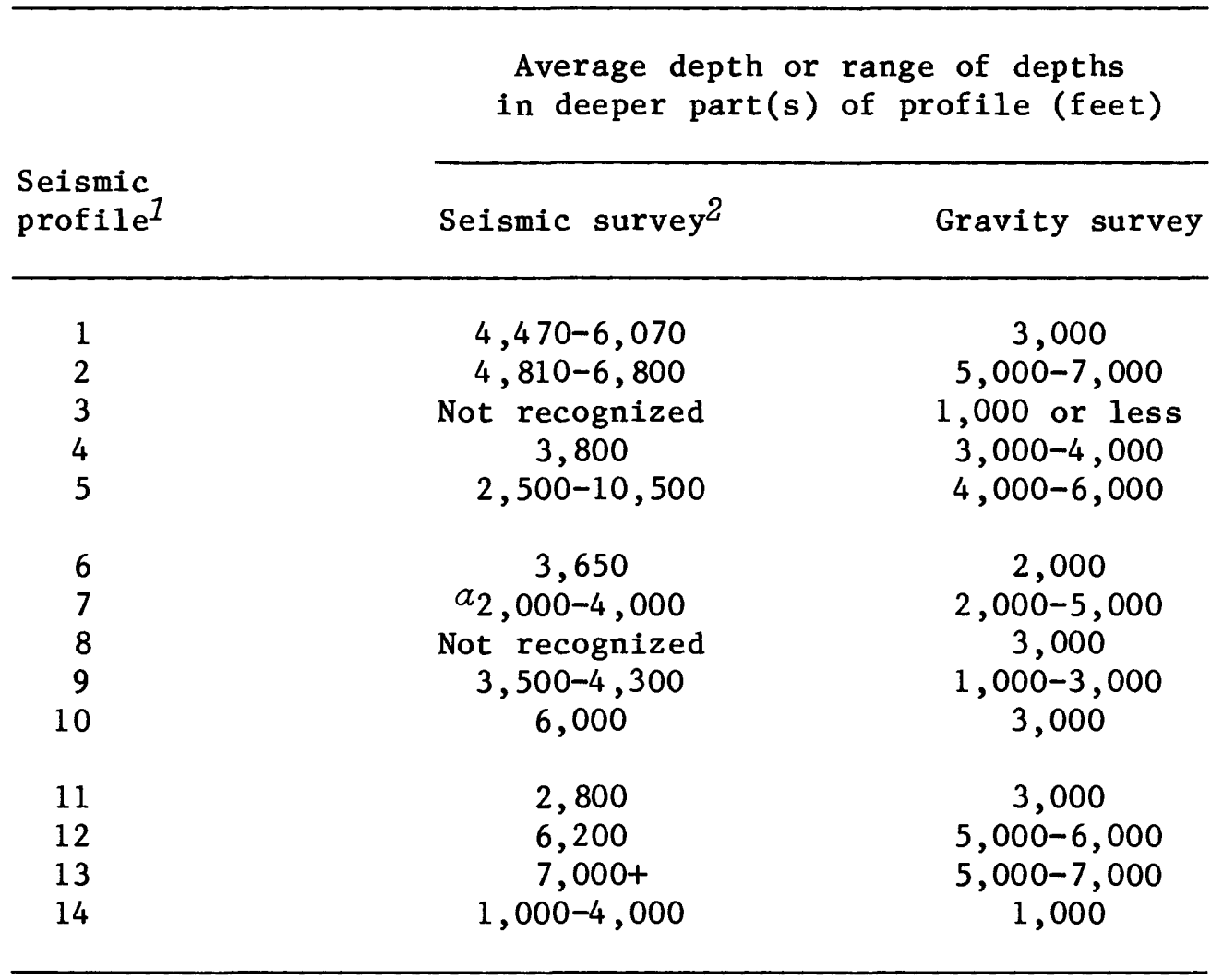

1 See figure 4 for location of profiles.

2 Depths from Meister, 1967, page 59.

a Depth estimated from Meister, 1967, page 39. 


\section{Limitations of the Survey}

As with any geophysical technique, errors in measurements and invalid assumptions make the final interpretation less than exact. Limitations of the equipment are sometimes unavoidable but nonetheless enter into the overall error of interpretation.

One source of error due to equipment limitations is the reproducibility of measurements. A study of reproducibility with the same gravimeter used in this study was done in the Black Rock Desert, nearly 100 miles northwest of Dixie Valley, and showed the error of reproducibility to be about $0.3 \mathrm{milliGal}$ (Schaefer and others, 1981).

The locations of stations as determined by the loran system are accurate to within about 60 feet or about 0.01 minute of latitude. This corresponds to a maximum error of $0.018 \mathrm{milliGal}$. The altitude of the gravity stations is probably accurate to \pm 5 feet, which can result in an error of $0.30 \mathrm{milliGal}$.

If the worst possible case is assumed in which altitude, latitude, and meter error are maximized, the Bouguer gravity values--and hence the residual gravity values used to compute depths to bedrock--could be in error by as much as 0.62 milligal. Computations for the depth model were tested using that value for maximum error, and the results indicate that depths could differ by as much as 300 feet; however, the average difference is only about \pm 100 feet.

Another potential source of major error is the assumed density contrast between bedrock and valley fill. To test the density assumptions, a sensitivity analysis was done for a representative profile by using the inversion program over a range of density values for the valley-fill deposits from $1.97 \mathrm{~g} / \mathrm{cm}^{3}$ to $2.37 \mathrm{~g} / \mathrm{cm}^{3}-$ a common range of densities for valley-fill-type materials, according to Telford and others (1976, page 25). The results, showing the errors and maximum depths computed for various density contrasts, are listed in table 2. A density of $1.97 \mathrm{~g} / \mathrm{cm}^{3}$ yields the smallest error, but depths calculated using this density seem to be too small when compared with depths obtained from seismic refraction.

\section{TABLE 2.--Maximum depths with different densities}

\begin{tabular}{cccc}
$\begin{array}{c}\text { Density of valley fill } \\
\text { (grams per cubic } \\
\text { centimeter) }\end{array}$ & $\begin{array}{c}\text { Density contrast } \\
\text { (grams per cubic } \\
\text { centimeter) }\end{array}$ & $\begin{array}{c}\text { Maximum depth } \\
\text { (feet) }\end{array}$ & Error ${ }^{1}$ \\
\hline 1.97 & 0.70 & 5,800 & 0.286 \\
2.07 & .60 & 7,400 & .356 \\
2.17 & .50 & 10,100 & .475 \\
2.27 & .40 & 15,500 & .699 \\
2.37 & .30 & 27,800 & 1.15
\end{tabular}

1 Calculated by (1) squaring the difference between measured and calculated gravities at each station along the profile, (2) summing the squares for the profile, and (3) taking the square root of the sum. 
RELATION BETWEEN BEDROCK CONFIGURATION, GEOTHERMAL DEVELOPMENT, AND SEISMICITY

On the basis of the amount of time and effort invested by energy companies to delineate and define the geothermal resources of Dixie Valley, there can be little doubt that these resources will be developed at some time in the future.

As to the effect of geothermal development in the valley, the relatively thick section of valley-fill deposits may, to some extent, act as a buffer to the interaction between thermal and nonthermal ground water. Numerous faults are apparent in the depth-to-bedrock configuration (plate 2). Whether the faults can act as conduits for the migration of poor-quality ground water would be a worthwhile topic of more detailed study, once major production in the valley has begun.

Some indication of the possible effects of geothermal production in this seismically active valley may be known when analysis of the seismic monitoring is completed. Preliminary results indicate little correlation between seismicity and steam withdrawal (H. M. Iyer, U.S. Geological Survey, written commun., 1980). Only one earthquake with a magnitude greater than 1.0 on the Richter scale was detected during the 2-month monitoring period. These preliminary results may not, however, reflect possible adverse effects of major production. 


\section{REFERENCES CITED}

Cohen, Philip, and Everett, D. E., 1963, A brief appraisal of the ground-water hydrology of the Dixie-Fairview Valley area, Nevada: Nevada Department of Conservation and Natural Resources Reconnaissance Report 23, 40 p.

Corde11, Lindrith, 1970, Iterative three-dimensional solution of gravity anomaly data: U.S. Geological Survey computer contribution no. 10, 12 p. Available only from National Technical Information Service, U.S. Department of Commerce, Springfield, VA 22161, accession no. PB-196979.

Corde11, Lindrith, and Henderson, R. G., 1968, Iterative three-dimensional selection of gravity anomaly data using digital computer: Geophysics, v. 33. no. 4, p. 596-601.

Dobrin, M. B., 1976, Introduction to geophysical prospecting [3d ed.]: New York, McGraw Hi11, 630 p.

Hayford, J. F., and Bowie, William, 1912, The effect of topography and isostatic compensation upon the intensity of gravity: U.S. Coast and Geodetic Survey Special Publication 10, 132 p.

Johnson, M. G., 1977, Geology and mineral deposits of Pershing County, Nevada: Nevada Bureau of Mines and Geology Bulletin 89, 115 p.

Laurila, S. H., 1976, Electronic surveying and navigation: New York, John Wiley and Sons, 500 p.

Meister, L. J., 1967, Part I. Seismic refraction study of Dixie Valley, Nevada, in Thompson, G. A., and others, Geophysical study of Basin-Range structure, Dixie Valley region, Nevada: Stanford, Calif., Stanford University Geophysics Department report, 72 p.

Plouff, Donald, 1977, Preliminary documentation for a FORTRAN program to compute gravity terrain corrections based on topography digitized on a geographic grid: Menlo Park, Calif., U.S. Geological Survey Open-File Report 77-535, 45 p.

Schaefer, D. H., Welch, A. H., and Maurer, D. K., 1983, Geothermal resources of the western arm of the Black Rock Desert, northwestern Nevada--part I, geology and geophysics: U.S. Geological Survey Open-File Report 81-918, $37 \mathrm{p}$.

Slemmons, D. B., 1957, The Dixie Valley-Fairview Peak, Nevada, earthquakes of December 16, 1954; geological effects: Selsmological Society of America Bulletin, v. 47, p. 353-375.

Slemmons, D. B., Jones, A. E., and Gimlett, J. I., 1965, Catalogue of Nevada earthquakes, 1852-1960: Seismological Society of America Bulletin, v. 55, p. 519-565. 
Telford, W. M., Geldart, C. P., Sheriff, R. E., and Keys, D. A., 1976, Applied Geophysics: Cambridge, England, Cambridge University Press, 860 p.

Thompson, G. A., and others, 1967, Geophysical study of Basin-Range structure, Dixie Valley region, Nevada: Stanford, Calif., Stanford University Geophysics Department report, 244 p.

Westphal, W. H., and Lange, A. L., 1967, Local seismic monitoring - Fairview Peak area, Nevada: Seismological Society of America Bulletin, v. 57, p. 1279-1298.

Willden, Ronald, and Speed, R. C., 1974, Geology and mineral deposits of Church111 County, Nevada: Nevada Bureau of Mines and Geology Bulletin 83, 95 p.

Zones, C. P., 1957, Changes in hydrologic conditions in the Dixie Valley and Fairview Valley areas, Nevada, after the earthquake of December 16, 1954: Seismological Society of America Bulletin, v. 47, p. 387-396. 